\title{
Low-Input Grassfed Livestock Production in the American West: Case Studies of Ecological, Economic, and Social Resilience
}

\section{By Matthew K. Barnes}

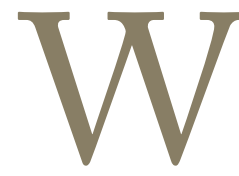

hen you're taking a product from the land ... all of the energy that we make use of comes from the sun," rancher Dennis Moroney reminded the audience at "Sustainable Rangelands Through Low-Input Grassfed Production" during the 2010 annual meeting of the Society for Range Management (SRM), cosponsored by the American Grassfed Association (AGA). The ecological resilience, economic viability, and social sustainability of grazing lands and the livestock industry can be maximized through grassfed livestock production, which relies on biological diversity and ecological complexity with minimal external inputs.

Grassfed livestock production keeps land in permanent vegetation, rather than annual crops that are harvested, trucked, and fed to animals in confinement. Potential benefits of shifting land use from cropland and feedlots to perennial pasture include reductions in soil erosion, pesticide and fertilizer use, and increases in biological diversity, soil fertility, and soil carbon sequestration. ${ }^{1}$

Relative to grain-fed beef, in terms of meat and protein production, grassfed beef can be more energy-efficient and more cost-efficient. ${ }^{2}$ The fossil fuel consumption of grassfed meat production only might be half that of grain-finished meat production, ${ }^{3}$ and Americans could still exceed their recommended daily allowance of animal protein without grain-finished meats. ${ }^{4}$ And, demand for alternative livestock products, such as grassfed, local, organic, and humanely raised, has risen in recent years; for instance, organic meat sales increased from negligible in 1997 to over $\$ 600$ million in $2008 ; 5$ and, according to a recent national survey of chefs, locally sourced meats and sustainability are the first and third ranked top food trends in $2011 .^{6}$
In this article, I summarize and synthesize the case studies, experiences, and observations of the symposium presenters, including ranchers producing grassfed beef or genetics primarily on western rangelands, dairy-farming veterinarians, the AGA and the Southwest Grassfed Livestock Alliance. AGA sponsorship enabled the ranchers to attend the session and those who spoke became members of SRM through Colorado Grazing Lands Conservation Initiative scholarships. Videos of the presentations are available on the Society for Range Management Web site at www.rangelands.org/ srvideos.

\section{The Virtues of Grassfed Products for Consumers}

"Windsor Dairy is about family-friendly farming and incorporating beauty into our lives," said Meg Cattell. She and husband Arden Nelson produce raw milk and raw milk cheese-Grade A, certified-organic, pasture-fed, from American Devon and milking Shorthorn cattle. The cheese is produced with no chilling, pumping, or heating, and is sold within 100 miles of Windsor, Colorado.

Windsor Dairy is converting old feedlots to pasture, using mob grazing, irrigation, and a pasture seed mix to restore degraded land. This involves no tillage but occasional drilling, and some mowing. "If we're not careful, we'll reinvent the prairie," Cattell said.

Cattell and Nelson both are veterinarians, and Windsor Dairy's livestock management promotes animal welfare: they have found that with planned rotational grazing and freedom of motion, their cattle are relatively free of disease. Windsor Dairy's organic herd has a clinical mastitis rate below $1 \%$, and a total death/cull rate of only 7\%, well below US averages, 


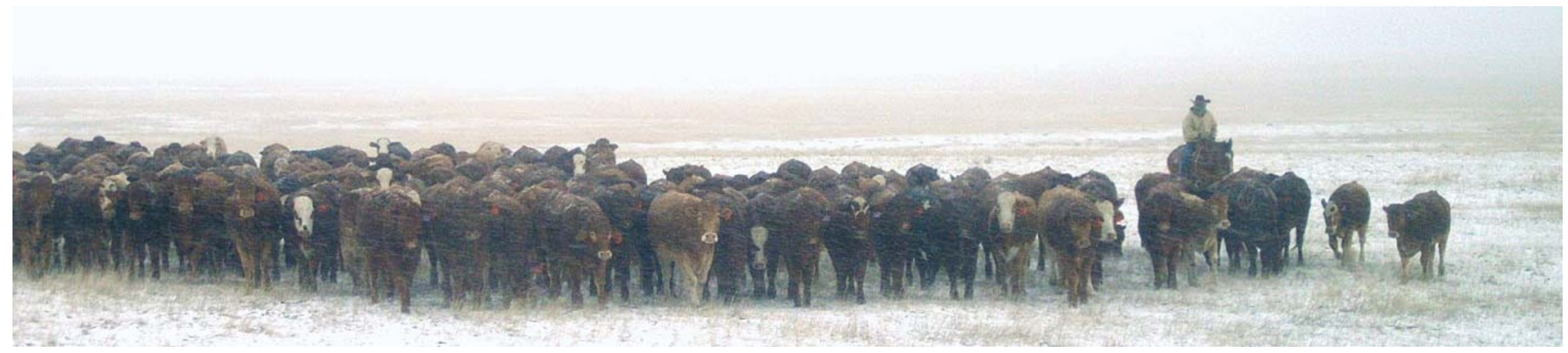

Figure 1. Grassfed Beefmaster cattle at the Lasater Ranch. Photo courtesy of Dan Nosal.

according to Cattell. Grain feeding, in contrast, increases rumen acidity, leading to acidosis (a common metabolic disorder of grain-fed cattle), ${ }^{7}$ and increasing concentrations of pathogens such as acid-resistant Escherichia coli. ${ }^{8}$

"We are reinventing real food," Cattell said. Windsor's milk is $4.5 \%$ fat and $3.8 \%$ protein, which is higher than whole milk from confined dairy cattle (3.3\% fat and 3.2\% protein $\left.{ }^{9}\right)$. Grassfed is usually leaner than grain-fed meat, and although the total saturated fatty acid content might be similar, the grassfed beef fatty acid profile can be more nutritious. ${ }^{10}$

Cattell asserted that grassfed beef, with its lower omega-6 to omega-3 ratio, might be a way of addressing human health issues associated with omega- 3 fatty acid deficiency. Published data vary, but some show that grassfed beef has more omega- 3 fatty acids, and a lower omega- 6 to omega- 3 ratio, on a gram-per-gram fat basis. ${ }^{10}$ Polyunsaturated, including omega-3, fatty acid concentration in meat decreases with days on grain feed. ${ }^{11}$

Grassfed raw meat and milk can have several times as much conjugated linoleic acid (CLA) as grain-fed products. ${ }^{12} \mathrm{~A}$ fatty acid found only in ruminant meat and dairy products, CLA has anti-inflammatory ${ }^{13}$ and anticancer ${ }^{14}$ properties in mice, but has not yet been conclusively shown to be significant to human health. ${ }^{15}$

In addition to human nutrition, grassfed production addresses natural resources conservation issues, including soil and water conservation, organic matter (carbon) sequestration, and wildlife and plant diversity. For example, Windsor Dairy's manure is low in phosphorus, unlike the manure of grain-fed cattle. Dung beetles recycle it into the soil. "There is a closed loop of nutrient cycling on the farm," said Cattell; this is as nearly a complete whole as a farm can be.

\section{Ranching in Sync With Nature}

Ranching in sync with nature on the prairie-stewardship of the land, forage, livestock, and wildlife-is "akin to heaven," according to Dale Lasater.

The Lasater Ranch, on the plains of eastern Colorado (Fig. 1), has focused on two of the central concepts of planned grazing - animal impact and long recovery periodssince learning about Holistic Management from Allan Savory in the early 1980s. ${ }^{16}$ The range has greatly improved; now only the cell centers are degraded, with some western wheatgrass (Pascopyrum smithii [Rydb.] A. Löve) coming into them. There are 11-15 paddocks adjacent to each cell center. The highest grass diversity in the paddocks tends to be closest to the cell centers. Cattle are moved by opening gates. Recovery periods are about 80 days during slow growth, which is most of the year.

Remnants of tall and midgrasses, such as switchgrass (Panicum virgatum L.), prairie sandreed (Calamovilfa longifolia [Hook.] Scribn.), sand bluestem (Andropogon hallii Hack.), and green needlegrass (Nassella viridula [Trin.] Barkworth) are returning to the shortgrass prairie. By grazing a cheatgrass (Bromus tectorum L.)-infested pasture early in the spring, the Lasater Ranch allowed perennial grass to return. The ranch has thriving wildlife populations: pronghorn (Antilocapra americana), mule and now white-tailed deer (Odocoileus hemionus and O. virginianus), wild turkeys (Meleagris gallopavo), many raptors, and at least 80 species of birds in one riparian area. They do not allow hunting of coyotes (Canis latrans), and their cattle are capable of defending themselves against them. They even have reintroduced black-tailed prairie dogs (Cynomys ludovicianus).

Laurence Lasater believed that livestock should be tested in the environment in which they are going to produce, allowing culling by natural selection. ${ }^{17}$ Tom Lasater developed the Beefmaster breed, a three-way cross between Hereford, Shorthorn, and Brahman cattle, during the Great Depression; the herd has been closed since 1937. The Lasaters stopped using insecticides in the 1960s, and their cattle now have few flies or lice, at least partly due to planned grazing. Many years ago Tom Lasater changed the calving season from February-March to August, which was a great improvement, but in order to be more in sync with the annual forage cycle, the ranch is now shifting the calving season back to June. Lasater Grasslands Beef is now sold on the internet and in Vitamin Cottage Natural Grocers stores in Colorado.

\section{Multiple-Species Grassfed Production}

The benefits of multiple-species grazing include improved diversity and utilization distribution, resulting in increased production and higher profit per acre, and reduced risk, said Richard Parry, a fourth-generation sheep rancher now also raising cattle, goats, chickens, and pigs at Fox Fire Farms in Ignacio, Colorado. Parry learned the principles of holistic 
planned grazing from Allan Savory and Stan Parsons in the 1980s. ${ }^{16}$

It is possible to increase total forage utilization significantly with sheep and cattle compared to cattle alone, due to a greater diversity of plant species being grazed; a higher stocking rate can be sustained under multiple-species grazing. ${ }^{18,19}$ Sheep select forbs, including many weeds, and will forage near cow dung. For instance, in Montana, sheep grazing for several years significantly reduced leafy spurge (Euphorbia esula L.) abundance. ${ }^{20}$ Goats prefer browse, and so even have less dietary overlap with cattle than do sheep. ${ }^{21}$ Pastured poultry mostly eat insects and seeds, but do graze some grass and forbs..$^{22,23}$

Multiple-species grazing can mitigate risk by diversifying income and allowing for multiple marketing opportunities each year. Producers considering different species of livestock should determine their centerpiece enterprise based on their competitive advantage and the species with the highest gross margin. Parry speculated that too many operations use cattle as the centerpiece even though they lack a competitive advantage and could yield a higher gross margin from other species. The net income should be at least half of the gross, and stacked or ancillary enterprises should feed off of surplus inputs and labor from the centerpiece.

Multiple-species grazing can be done with leader-follower, flerd, or complementary grazing (Fig. 2). In leader-follower grazing, the animals with the highest nutrient requirements graze a paddock ahead of animals with lower requirements, in a single grazing period. For instance, with sheep and cattle, stocker cattle should lead, followed by sheep, then cow-calf pairs, with dry cows last. A flerd is a flock of sheep bonded to a herd of cattle, usually in pen confinement for 14-30 days. The flerd then will stay together, but the cattle will not necessarily protect the sheep or goats from predators, so guardian animals still are recommended. In complementary grazing, the flock and herd are kept separate and graze in an alternating rotation from one grazing period to the next. One species conditions the paddock for the next, as in leader-follower grazing, but with a recovery period in between.

Many ruminant parasites have about a three-week life cycle; Parry has found that parasite loads can be reduced by rotational or planned grazing that involves short graze periods followed by a month or longer nongrazing interval. Multiple-species grazing with sheep or goats plus cattle can further reduce parasite loads, especially in complementary grazing, because sheep and goats are dead-end hosts for cattle parasites, and vice versa. However, sheep and goats do share many parasites, and should be kept separate from each other, especially in organic operations. Animals identified as carriers should be culled.

\section{Benefits of Low-Input Ranching}

"Agriculture that is not profitable and enjoyable will never be sustainable," Kit Pharo of Pharo Cattle Co. in eastern
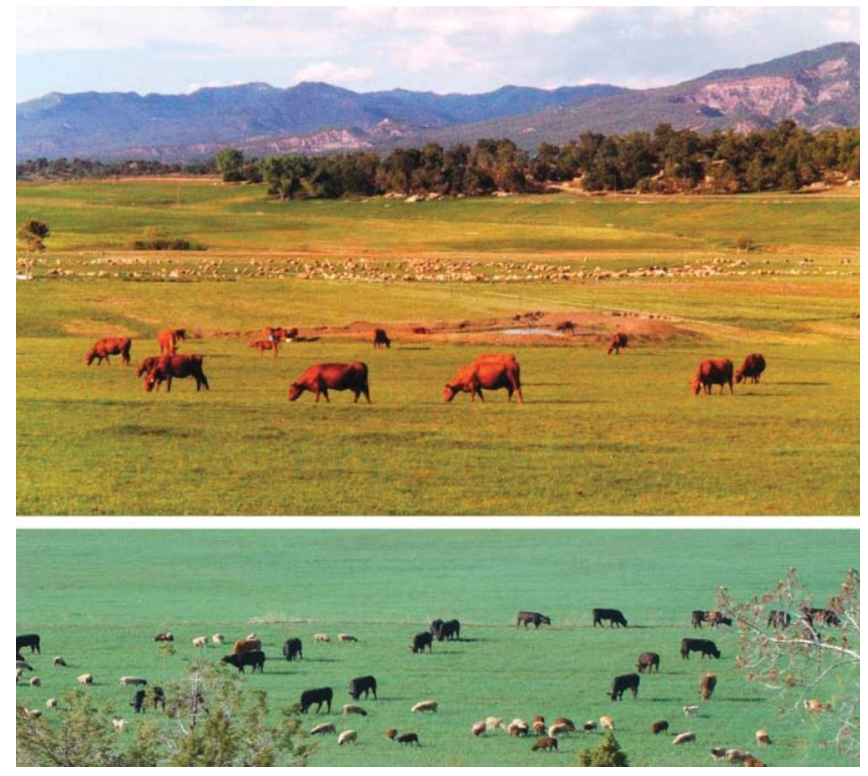

Figure 2. Sheep and cattle in leader-follower grazing (above) and a flerd (below). Photos courtesy of Richard Parry.

Colorado is fond of saying. Profitable ranches make the most efficient use of their forage resources. Although the average producer might break even over the course of the cattle price cycle, the low-input producer might be able to make a profit most years if not every year.

Over the last four decades, Pharo has observed that input costs have risen five times faster than cattle prices. He speculated that the beef industry might be at a tipping point: what has worked so well for the past 40 years probably will not work for the next 40 years. Whereas most industries accept and implement change within about two years, his experience is that the livestock industry seems to take about two decades to accept and implement proven concepts. Pharo sees as a problem that the generation currently working the land is often living in their parents' paradigm. The producers who dare to quit the herd-mentality way of thinking are the ones who are leading the change, rather than being led by it. Following the crowd is seldom the best way to manage a business because it forfeits any possible competitive advantage.

Pharo asserted that to increase their profit potential, ranchers should produce a differentiated product rather than an undifferentiated commodity (e.g., grassfed beef vs. feeder calves). This is not easy: it requires planning, managing, and marketing. A producer needs to believe in their product in order to market it.

Pharo identified three keys to increasing efficiency and profit in the livestock business, which can be summed up as ranching in sync with nature. His first key is planned rotational grazing, although he sees only a small number of ranches actually applying it. Planned rotational grazing can improve range and pasture health, and thus increase livestock production. ${ }^{24}$ Pharo said that he has increased 


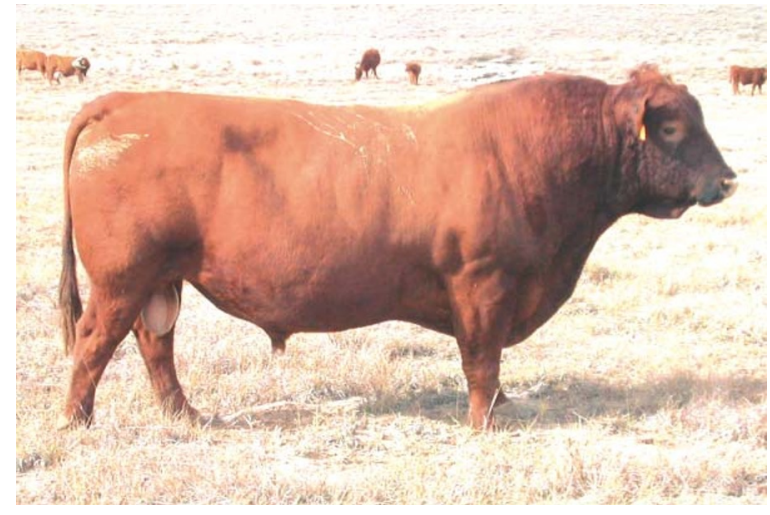

Figure 3. A 2,250-pound bull with a frame score of 4.5 (52 inches tall at the hip), a biological type bred to sire grassfed cattle. Photo courtesy of Kit Pharo.

cattle production by $50 \%$ since 1994 with planned grazing. It also can help reduce or eliminate supplemental feeding: Pharo now only feeds hay when the snow is too deep and crusted for cattle to dig through.

His second key is matching the livestock production cycle to the forage cycle. ${ }^{25}$ In most of North America, this means calving in May and June, as elk and deer do. Pharo said that this can reduce feed and labor costs by $70 \%$, and most producers then might be able to eliminate all winter feeding except in emergencies. Pharo's experience, working with many cattle ranchers across the United States, is that if calving in May and June, the vast majority of calves will be born without calving problems and in the first 30 days of the calving season. Individual weaning weights will be lower than with winter/spring calving; however, with reduced death losses, he noted, a producer can usually wean more total pounds, which are worth more per pound because of the price slide.

His third key is matching livestock size and type to the forage resources. "I want a cow that can support the ranch, instead of being supported by the ranch," Pharo said. "Require cattle to live within their means." Livestock need to fit their environment, ecologically and economically, rather than having their environment artificially changed to fit them. For instance, Pharo's inputs essentially have been reduced to vaccinating calves at weaning, and providing a 50/50 mixture of salt and mineral; he does not vaccinate cows, or use insecticides or wormers. He finds fertility to be more important than growth, and biological type more important than breed. Pharo's optimum cow is a two-to-four frame cow that weighs 1,000 to 1,200 pounds; bulls of the same frame score are larger (Fig. 3). Smaller cows wean a higher proportion of their body weight, while eating less.

Ranchers, especially grassfed livestock producers, are in the business of converting free solar energy into a high-quality food product. Properly done, the livestock will do nearly all the work. Pharo finds that keeping it simple (low-input) is the way to keep it profitable — and enjoyable.

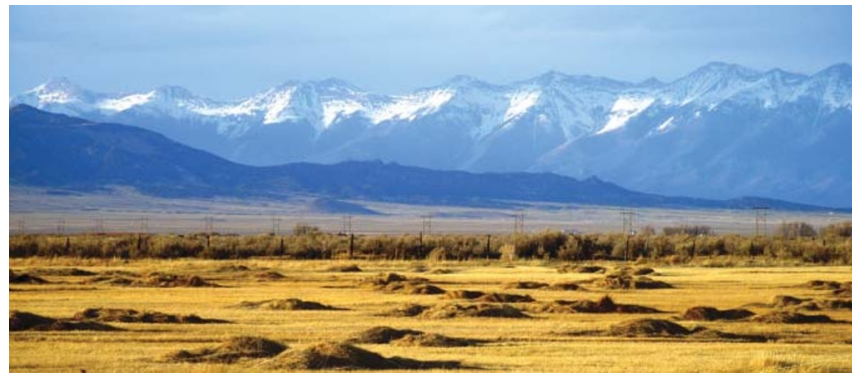

Figure 4. Piled hay on the San Juan Ranch requires less energy input than baled hay, and is rationed out over the winter along with meadow aftermath as complementary forage to native range. Photo by Matt Barnes.

\section{Organic Grass-Finished Beef on a Forage Chain From Conception to Consumer}

George Whitten was raised in the pastoral sheep camps of Colorado's San Luis Valley, where the flocks and herds were controlled by drought, snow, the flu, and, before Whitten's time, conflicts with American Indians. Whitten has spent his lifetime figuring out how to live in the ecosystem, and meeting Allan Savory helped him discover how to do this. ${ }^{26}$ "Allan taught me a whole new way to look at the world," Whitten says. "The answer is literally beneath our feet."

Shortly after Julie Sullivan came to San Juan Ranch, she told Whitten that she could not ranch if it meant sending animals to feedlots, and he agreed. They now produce organic grassfed beef, finished on a forage chain and directmarketed to consumers. 'Unfortunately, the term 'organic' has been marketed into meaninglessness," Sullivan said, "but we try to be true to the real meaning of the word. One of the dictionary definitions of 'organic' is the fundamental constitution of a thing, and grassfed is the inherent, inborn, constitutional reality of a cow."

Pastoralism was, and is, a way of life with promise for the future. Although grassfed livestock production is relatively low-input, pastoralists always have invested in a high-maintenance relationship with their land and livestock (Figs. 4 and 5).

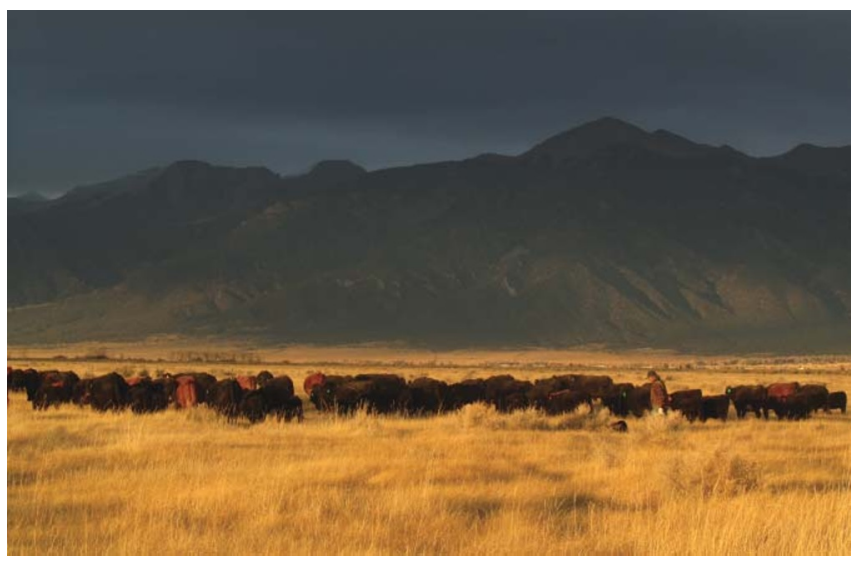

Figure 5. George Whitten uses his herd of organic grassfed cattle to manage vegetation on the Baca National Wildlife Refuge with rotational grazing and low-stress livestock handling. Photo by Matt Barnes. 
Some inputs are high: time, love, and deep thinking directed by values. According to Sullivan, "our ranch is a high maintenance ranch because it demands our time and love, and like our marriage, it reflects the quality and quantity of time spent together. Agriculture lost part of its soul when we started calling it 'management' rather than stewardship, husbandry, or partnership. Think about the word 'manage'; You might try to manage your partners, but you'll rarely be successful," Sullivan said as she and Whitten exchanged knowing smiles.

They see their ranch as a partnership between the land and the animals, from soil microbes to cattle to dung beetles to people, including not only the agrarian ranchers but also their interns, customers, and colleagues in organizations such as Holistic Management International and the Quivira Coalition. All these partners are equals, and each brings a new opportunity.

Whitten and Sullivan will not do anything for a cow that she can do for herself. They feed hay in the winter, but they do not bale it. They cut and swath it, and then rake it into piles about the size of a small square bale, so that it does not blow away in the fierce spring winds. The piles are rationed out over the winter by strip grazing with electric fence, so that the nutrients are recycled back into the ground right there, rather than transported and concentrated (Fig. 4). ${ }^{27}$

During the severe drought of 2003, they took their cows to New Mexico for a revegetation project at Kirtland Air Force Base. The land had been disturbed heavily by military operations and was returned to the state with an agreement to restore it to something like its natural condition. It had been seeded and mulched, but only sparse rows of fourwing saltbush and a few annuals had become established in a matrix of bare ground, much of it exposed caliche. Whitten and Sullivan fed their cows hay at a stock density of 300 animal units per acre, moving the herd with electric fence every day. The distance between perennial plants decreased dramatically in the first year. ${ }^{28}$

Whitten and Sullivan worked with the Baca National Wildlife Refuge, an old Spanish Land Grant in the San Luis Valley, to continue agriculture while managing for ground-nesting birds and controlling invasive weeds without chemicals. Local customers often see Whitten and Sullivan's cattle grazing on the refuge (Fig. 5) before they buy their beef at the farmers' market, and some of those customers are so loyal, they have gone out on the San Juan Ranch BLM allotment to pull black henbane (Hyoscyamus niger L.) by hand. To Whitten and Sullivan, this exemplifies their belief that ranching is a partnership of many players engaged in mutual and reciprocal support.

They sell about 100 finished animals per year, but think the market is much bigger, so are working on a cooperative with other ranchers who can meet their criteria. An animal can finish in 18-24 months and grade high select to low choice. They do an ultrasound test to predict a tenderness score, and only those animals that pass will be marketed as grass-finished.

Whitten and Sullivan define success as harmony with others: a life and a ranch that is humane, with secure finances, and that helps create a socially just world. They said that wholesome food is for everyone, not just a niche market for "food yuppies."

\section{The Low-Carbon Foodprint of Local Grassfed Livestock Production in a Semiarid Environment}

Dennis and Deb Moroney and their family are "becoming native" on the 47 Ranch in southeastern Arizona, a double challenge of restoration and production. The arid and semiarid Southwestern landscape has been degraded, like much of the American West, with the most severe damage done a century ago by well-meaning people who did not understand their environment. ${ }^{29}$ Still, they find the cowboy/vaquero culture is the closest thing to combining Euro-American and indigenous fabrics of living, and, where it is merged with an ecological understanding of the land, the emergent lifeway can be considered the most appropriate, and native, to the region.

The Moroneys found commodity livestock income could not make the payment on their ranch, even in a year of ideal climatic conditions. Desperation is the mother of creativity, and the traditional cow-calf paradigm was clearly not sustainable for the 47 Ranch, so Moroney started looking for pre-fossil-fuel-era models to reduce its carbon footprint. Carbon sequestration means increasing the organic matter in the soil. For Moroney, this requires planned grazing as well as finishing animals on range or pasture to reduce the total carbon footprint relative to finishing on harvested and transported feeds.

The ranch, with approximately 50\% mountains and 50\% desert grassland, uses planned rotational grazing with 24 paddocks. The overall pattern is reverse transhumance, because the cool-season grass in the mountains grows in the winter, and the warm-season grass in the lower country grows in the summer monsoon. In the spring, cattle eat the mesquite (Prosopis spp.) beans on the desert grassland.

"Genetics is our link to a more sustainable past," said Moroney. He selects animals for calm disposition, as well as the ability to adapt to the changing conditions, biodiversity, and poisonous plants of, and ability to finish on, the ranch's native rangeland.

"I haven't seen 10 calves born in the last 20 years," Moroney said. Some of them die, which is natural culling as well as nutrient cycling. Predators are partners: they control the rabbits and rodents. To prevent losses to predators, the sheep and goat herds are penned every night during lambing and kidding (Fig. 6).

The Moroneys see endangered species as a form of wealth, even though - and partly because-their presence reduced the ranch's market value. There is now a conservation 


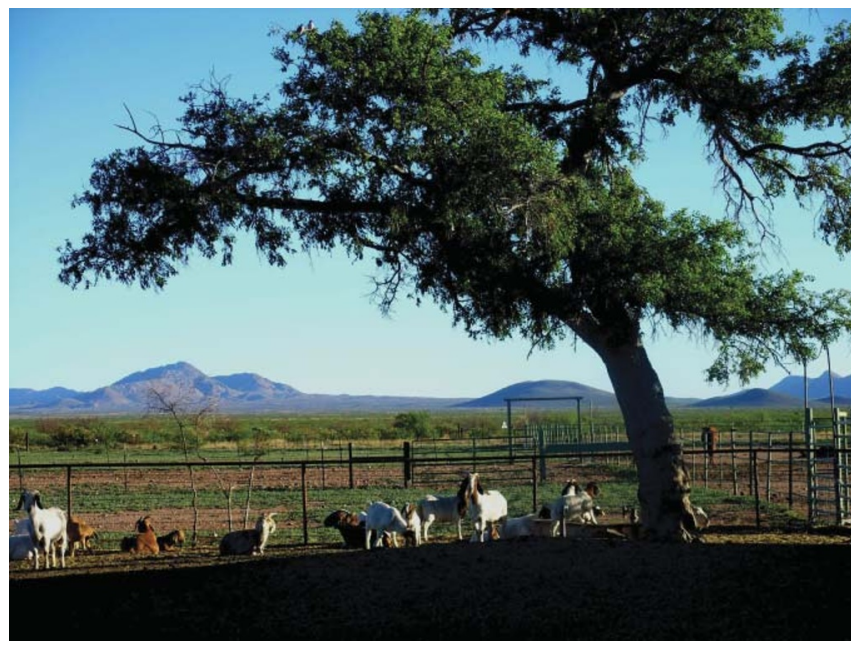

Figure 6. Grassfed goats on the 47 Ranch. Photo by Matt Barnes.

easement on 1,000 acres that had several listed species. The ranch sold the development rights to the Arizona Game and Fish Department, and used the money to pay off the mortgage. The ranch retains the agricultural rights, and its only debt is an operating loan. Southeastern Arizona is under increasing development pressure, and part of the ranch's goal is for all but a small portion to be under easement.

Using renewable energy is part of reducing the carbon footprint. The 47 Ranch already has 20,000 watts of solar panels to run the headquarters and pump water. They are net metering with their local power company, and investigating opportunities for wind power generation.

Sky Island Brand grassfed beef, lamb, and goat meat are marketed directly to consumers in southern Arizona. Currently this includes selling at farmers' markets; the ranch is also starting a buyers' club. The quintessential meal of the Arizona-Sonora borderlands, tacos al carbón, made of grassfed beef, sheep, or goat, with wild-harvested chiltepines (Capsicum annuum L. var. glabriusculum [Dunal] Heiser \& Pickersgill) on a Sonora wheat tortilla, can be called tacos sin carbon for its low-carbon footprint. Moroney and his colleagues in the Sabores Sin Fronteras (Flavors Without Borders) Foodways Alliance are pursuing grant funding for a taco truck that not only would sell this and other low-footprint local foods, but also would use digital screens to educate consumers about ranching and managing land to sequester carbon. ${ }^{30}$

\section{Desert-Adapted Cattle: Harvesting the Past for the Future}

The more you learn, the less you know-and developing beef cattle production systems adaptable to changing socioeconomic and climatic conditions in the arid and semiarid lands of the southwestern United States is challenging everything Ed Fredrickson, Alfredo Gonzáles, Gerardo Bezanilla, and José Ríos were taught. Their joint United StatesMexico project was designed to identify the physiological and behavioral traits of desert-adapted beef cattle, in order to

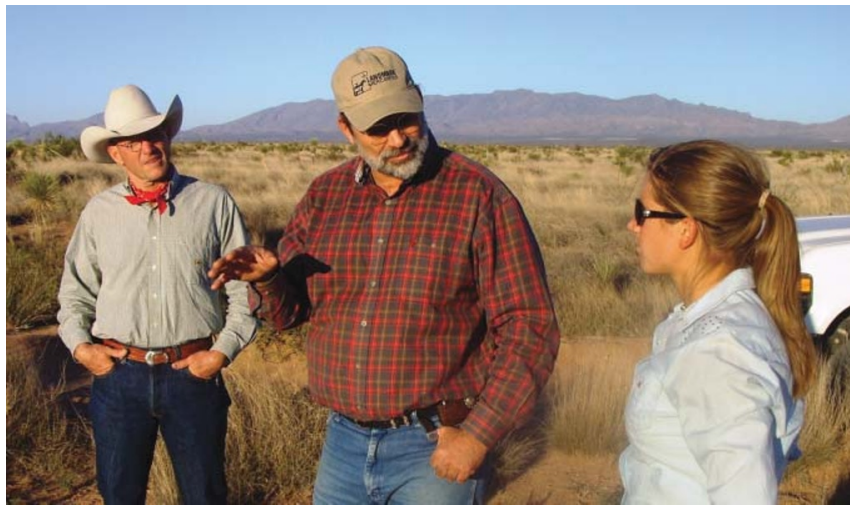

Figure 7. Michael Bain (Southwest Grassfed Livestock Alliance; SWGLA), Ed Fredrickson (USDA Agricultural Research Service), and Vanessa Prileson (New Mexico State University) discussing desertadapted livestock and grazing management at the Jornada Experimental Range during a SWGLA workshop. Photo by Matt Barnes.

eliminate supplemental feeds, use less water, reduce the carbon footprint of beef production, and increase profitability to the producer (Fig. 7).

During 1915, the average weight of a beef cow on the Jornada Experimental Range in southern New Mexico was 735 pounds, with Hereford bulls introduced during the 1910s to breed with the Spanish criollo cattle or "Chihuahuas" that occupied the desert southwest during the prior 300 years. Cow size gradually increased through the 1960s, followed by a much larger increase in body weight with the introduction of continental breeds in the 1970s. Now the typical cow of the southwestern United States can be 1,200 to 1,400 pounds, and often requires a steady diet of supplemental feeds during all but exceptional years.

Believed to be adapted to the arid and semiarid Atlas Mountains of Morocco and Algeria, criollo cattle probably were brought to the Iberian Peninsula by the Moors around 900 AD. Arriving in the Americas in 1493 with Columbus's second voyage, these cattle were introduced to Mexico in 1521, and about 7,000 were trailed to New Mexico by Oñate in $1598 .{ }^{31}$

Using genetic testing, the researchers found two pure populations in northern Mexico: one in the Sierra Tarahumara of Chihuahua, and the other in San Ignacio, a 3-inch precipitation zone in Baja California Sur. The Chihuahuan criollos weigh about 800 pounds at mature size and the San Ignacio criollos, called Chinampo cattle, are even smaller at 600 pounds.

When compared to British breeds, both criollo and black baldy (Angus $\times$ Hereford) cattle visited water daily, but criollo cattle spent less time per day loafing near water (30 minutes vs. 3 hours). Criollo cattle traveled further from water, traveled faster, and used a larger area with more diverse vegetation types (e.g., tobosa grass and mesquite thickets) than British breeds. ${ }^{32,33}$ Fredrickson said they also exhibited higher heat tolerance, reached puberty earlier; and that others describe greater calving ease and a shorter postpartum interval. 
Currently these animals are too small for today's commodity market at 800 pounds mature weight, but there is substantial regional interest in desert-adapted, or heritage beef for grassfed markets. In one test they sold 3,000 pounds of criollo beef in two weeks in a locally owned grocery. The meat is dark red, possibly because it has more red than white muscle fibers. Fredrickson said several people have observed that criollo cattle also partition energy differently than other breeds, putting more energy into internal and intramuscular fat and less into backfat. They also heard that many consumers indicated that it was more flavorful than store-bought, commodity beef.

\section{Benefits of Grazing Systems to Grassfed Production}

Harvey Sprock provided a brief primer on grazing systems in grassfed livestock production. Grassfed livestock production is not sustainable without proper management, both in terms of stocking rate and planned grazing involving appropriate recovery periods. ${ }^{34,35}$ With long grazing periods or insufficient nongrazing intervals, preferred species and parts of the landscape are grazed more heavily than the pasture as a whole. ${ }^{36,37}$ For instance, on sandy sites there is often wind erosion under continuous grazing, even when "properly" stocked.

Natural grazing systems involve migratory mammalian herbivores, such as American bison (Bos bison), with grazing in any one place being patchy and of varying intensity, but almost always of short duration and usually not occurring more than about once per year. ${ }^{38}$

Plants compete for water and nutrients; in the case of grass, this primarily is through the root system, which comprises approximately three-fourths of its biomass. When a grass plant is grazed severely-below its growing point-it kills off some roots to initiate new tiller growth. It takes leaves to make leaves, and any plant grazed repeatedly without adequate recovery is at a competitive disadvantage with its neighbors.

The ideal grazing period should be short enough to prevent repeat grazing of preferred species once aboveground regrowth begins. Based on Sprock's experience, in most temperate steppe environments, this is less than seven days during the growing season.

Even more important than a short grazing period is a nongrazing period adequate for full recovery of grazed plants, so that they no longer are at a competitive disadvantage with nearby ungrazed plants. The time required for recovery varies widely between sites and with environmental conditions on any one site. ${ }^{24}$ Experimental data are lacking, but the experience of rangeland management specialists in Colorado is that recovery on most temperate steppe rangelands should be at least a month to a month and a half during fast growth, and at least three months during slow growth, ${ }^{39}$ or most of the growing season. ${ }^{24,40}$ In more arid environments, during drought, or on severely degraded rangelands, recovery might require a year or more. ${ }^{41}$ During the "dormant" season there is no effective recovery. ${ }^{24,38}$

Grasses really do not go completely dormant, because they have overwintering tillers. Differences in palatability remain through the "dormant" season, so rationing out the stockpiled forage through planned grazing still can spread the use of the more palatable plants over the course of the season. Sprock noted that native grazers survive the winter without supplementation, by timing calving and early lactation to coincide with fast growth, and by putting on enough fat in the summer that they can afford to lose condition in the winter. Cattle can do this too, as long as there is stockpiled forage available.

Planned rotational grazing-moving a herd through a series of paddocks based on plant growth, use, and recovery rates-is particularly effective where there is a wide range of palatability between plant species, such as a mixture of cooland warm-season grass. On the western Great Plains of North America, much of the landscape is dominated by low-statured, mat-forming grasses tolerant of heavy grazing, hence the name "shortgrass prairie." ${ }^{" 2}$ However, changing the grazing management to prevent repeated use of preferred species will allow those species, such as wheatgrasses and bluestems, to reestablish themselves. For example, when the Lasater Ranch started planned rotational grazing, Sprock said, "The tall grasses virtually exploded."

\section{Rebuilding Food System Infrastructure in the Southwest}

The Southwest Grassfed Livestock Alliance (SWGLA) provides support, workshops (Fig. 7), and other resources for producers in New Mexico, Colorado, Arizona, and Utah. SWGLA Executive Director Laurie Bower noted that even though $97 \%$ of southwestern consumers prefer local meat, and $13 \%$ would be willing to pay a $20 \%$ premium for it, only about $1 \%$ of New Mexico beef is consumed locally, according to the New Mexico Beef Initiative Survey (unpublished). She said that a typical New Mexico steak might travel about 3,000 miles from pasture to plate via feedlot finishing, processing, and distribution back to New Mexico, according to Farm to Table (unpublished), a nonprofit organization promoting local and sustainable agriculture in New Mexico.

The SWGLA has found that the greatest barrier to economic viability of grassfed production for most small family farms and ranches (particularly in the Southwest) is the lack of available, affordable, USDA-certified processing facilities. This issue has become a priority for SWGLA, which is working to connect stakeholders who have an interest in rebuilding the food system infrastructure in the Southwest so that producers can serve the demand for fresh, healthy locally grown and processed meats. ${ }^{6}$ Grassfed meat is not just a niche market, but one with the potential to reach $20-25 \%$ of the US Beef market, according to Allen Williams of Tallgrass Beef.

Grassfed meat and dairy products also are an ecological imperative for all the reasons mentioned previously: the use 

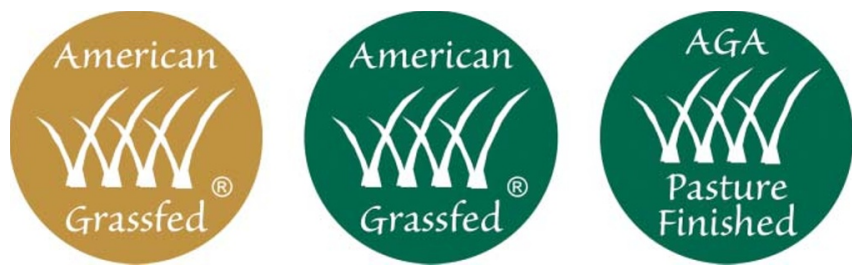

Figure 8. American Grassfed Association certification labels. L-R: Tier 1 -the gold standard-is animals raised on a 100\% forage diet for their entire lives. Tier 2 animals may be supplemented with approved nonforage feed during periods of low forage quality or inclement weather, but not to exceed $25 \%$ of their daily intake or $1 \%$ of their lifetime intake. Tier 3, "Pasture Finished" animals may be fed nonforage supplements up to $0.5 \%$ of daily intake during the growth stage and $1 \%$ of daily intake during the finishing stage.

of native, or at least perennial forage, with carbon in the soil, rather than soil carbon loss through annual cropping, transportation, and bare-ground feeding; nutrients spread over pastures as fertilizer, rather than concentrated in feedlots as pollution; and both livestock and human health. Bower summarized her, and the previous ranchers' presentations: grassfed products promote better human health, animal health, and environmental health, while preserving smallscale, family-run agriculture-thus improving food security and economic resilience for rural communities.

\section{American Grassfed Certification: Paperwork Behind the Promise}

The American Grassfed Association (AGA) is a producer-run organization for the promotion and certification of grassfed ruminant production. Carrie Balkom AGA's Executive Director, reported that "grassfed" now has a legal definition, requiring a $100 \%$ forage-based diet, but animals can be temporarily confined and fed antibiotics. "Grass-finished" has no legal definition, but normally is used to indicate that animals are not only grassfed but have been grown to mature size with marbling in the meat.

American Grassfed certification means that a product has met the legal definition, and that the animals were not raised in confinement and that they were born, raised, and processed in the United States. Thus, certification differentiates a product from foreign imports as well as confined-animal products marketed as "grassfed." There are three tiers of certification with three different labels (Fig. 8).

In addition to American Grassfed certification, AGA offers a simultaneous Animal Welfare Approved (AWA) certification and label at no extra cost.

Certification is performed through a reputable thirdparty audit, free to AGA members. The auditors are producers. The site visit usually takes one to four hours, and the entire process usually takes two to three weeks.

\section{Resilient Rangelands Through Low-Input Grassfed Livestock Production}

There is growing evidence that ruminants are healthier when grazing range or pasture rather than being fed harvested grains in confinement, ${ }^{7,8}$ and that these health benefits then can be passed on to the consumers of grassfed meat and dairy products ${ }^{8,10,11,15}$ (Cattell and Nelson). A forage diet and freedom from confinement are the essence of the definition of "grassfed" and central to both American Grassfed and Animal Welfare Approved certifications (Balkcom).

Grassfed livestock products appear to be an expanding segment of the overall US livestock industry. The six producers in the session implied that their grassfed enterprises were profitable, but most indicated that these enterprises require more skill and investment in business planning, marketing, and overall management. A producer has to believe in their product in order to sell it (Pharo), especially in direct marketing enterprises, where customers are effectively the producer's partners (Whitten and Sullivan). The local grassfed meat industry currently has a bottleneck at the processing stage (Bower).

Two of the producers were certified organic (Cattell and Nelson; Whitten and Sullivan) and Whitten and Sullivan emphasized grass-finishing their beef, i.e., raising the animals to mature weight with marbling fat, rather than selling younger animals. Half of the producers sold their grassfed products locally (Cattell and Nelson; Whitten and Sullivan; Moroney), whereas Lasater relied on internet sales. Pharo was in the seedstock business, selling forage-tested genetics to grassfed beef producers, rather than directly marketing grassfed meat.

Land stewardship was a common theme with two producers specifically using livestock as a tool for restoration projects (Cattell and Nelson; Whitten and Sullivan). Using multiple animal species in their operations was common among half the producers (Cattell and Nelson; Parry; Moroney), and most emphasized the importance of having animals that are adapted to the local environment, ${ }^{25}$ whether in terms of species (Parry; Moroney), breed (Cattell and Nelson; Lasater; Moroney; Fredrickson et al.) or biological type (Pharo). Beef cattle for grassfed operations, especially on semiarid to arid rangelands, should be relatively small in overall body size (Pharo; Whitten and Sullivan; Fredrickson et al.).

All of the producers said that they used some form of rotational grazing, ${ }^{24}$ and most referred specifically to holistic planned grazing, or said that they had learned grazing management from Allan Savory ${ }^{16,35}$ or others in Holistic Management ${ }^{38}$ (Lasater; Parry; Whitten and Sullivan; Moroney). The basic principles of planned rotational grazing were explained by Sprock. Goals of grazing management included optimizing stocking rate, maximizing the proportion of total aboveground plant biomass harvestable as forage, and maximizing biological decomposition of plant matter in the animals' digestive tracts, thus returning carbon to the soil rather than releasing it to the atmosphere through oxidation of standing dead material. ${ }^{35,38}$ The producers were able to maintain livestock performance with planned rotational grazing. ${ }^{43}$

All of the producers said that their grassfed operations were low-input compared to feedlot operations. ${ }^{2}$ Most 
emphasized that their livestock must produce with few external inputs, including help from their owners (Lasater; Pharo; Whitten and Sullivan; Moroney; Fredrickson et al.). Whitten and Sullivan stressed that although material inputs might be low, planning and management inputs are high. ${ }^{35}$

Most of the producers were members of AGA, SWGLA, or both. Whitten and Sullivan explicitly mentioned their partnership with Holistic Management International. Two partnered with the Quivira Coalition, and participated in the Quivira Coalition's Conservation And Ranching Leadership and Youth (CARLY) program to train ranching apprentices (Whitten and Sullivan; Moroney). Only Moroney previously was a member of the SRM.

The rancher-focused session brought producers into the SRM conference, and might have increased the perceived relevance of rangeland management and SRM to the ranchers' operations. Sponsorship by AGA made it financially viable to have ranchers as invited speakers. Several progressive and conservation-minded producers became members of the SRM as a result of this partnership and the rancher scholarships provided by the Colorado Grazing Lands Conservation Initiative.

\section{Acknowledgments}

The symposium "Sustainable Rangelands Through LowInput Grassfed Production" was organized by Dan Nosal, Harvey Sprock, and Matt Barnes, Rangeland Management Specialists with the USDA Natural Resources Conservation Service in Colorado and members of the SRM and the AGA; and by Carrie Balkcom, Executive Director of the AGA. Producers who spoke were supported by the AGA, and scholarships from the Colorado Grazing Lands Conservation Initiative and Roy Roath. Ben Berlinger, Kimberly Diller, Mark Mosely, Josh Saunders, and Jenny Stricker provided volunteer assistance. Videos of the session were sponsored by USDA-NRCS Colorado, and are available at www.rangelands.org/srvideos/.

\section{References}

1. Culman, S. W., S. T. DuPont, J. D. Glover, D. H. Buckley, G. W. Fick, H. Ferris, and T. E. Crews. 2010. Long-term impacts of high-input annual cropping and unfertilized perennial grass production on soil properties and belowground food webs in Kansas, USA. Agriculture, Ecosystems \& Environment 137:13-24.

2. Сook, C. W., J. W. Walker, M. H. Ebberts, L. R. Rittenhouse, E. T. Bartlett, D. A. Cramer, P. T. Fagerlin, and M. C. McKean. 1981. Alternative grass and grain feeding systems for beef production. Colorado State University Experiment Station Fort Collins Bulletin 579S. 101 p.

3. Pimentel, D., And M. H. Pimentel. 2008. Food, energy, and society. 3rd ed. Boca Raton, FL, USA: CRC Press. 402 p.

4. Pimentel, D. 1997. Livestock production: energy inputs and the environment. In: S. L. Scott and X. Zhao [EDS.]. Proceedings of the 47th Annual Meeting of the Canadian Society of Animal Science; 24-26 July 1997; Montréal, Québec, Canada. p. 16-26.
5. Dimitri, C., And L. Oberholtzer. 2009. Marketing U.S. organic foods: recent trends from farms to consumers. USDA Economic Research Service Economic Information Bulletin No. 58.27 p.

6. National Restaurant Association. 2010. Chef survey: what's hot in 2011. Available at: http://www.restaurant.org/ pdfs/research/whats_hot_2011.pdf. Accessed 10 January 2011.

7. Owens, F. N., D. S. Secrist, W. J. Hill, and D. R. Gill. 1998. Acidosis in cattle: a review. Journal of Animal Science 76: 275-286.

8. Diez-Gonzalez, F., T. R. Callaway, M. G. Kizoulis, and J. B. Russell. 1998. Grain feeding and the dissemination of acid-resistant Escherichia coli from cattle. Science 281(5383):1666-1668.

9. USDa National Agricultural Library. 2010. National nutrient database for standard reference. Available at: http:// www.nal.usda.gov/fnic/foodcomp/cgi-bin/list_nut_edit.pl. Accessed 28 December 2010.

10. Daley, C. A., A. Авbott, P. S. Doyle, G. A. Nader, And S. LARson. 2010. A review of fatty acid profiles and antioxidant content in grass-fed and grain-fed beef. Nutrition Journal 9(10):1-12.

11. Duckett, S. K., D. G. Wagner, L. D. Yates, H. G. Dolezal, AND S. G. May. 1993. Effects of time on feed on beef nutrient composition. Journal of Animal Science 71:2079-2088.

12. Dhiman, T. R. 2001. Role of diet on conjugated linoleic acid content of milk and meat. Journal of Animal Science 79(Supp.1):241.

13. Zulet, M. A., A. Marti, M. D. Parra, and J. A. Martínez. 2005. Inflammation and conjugated linoleic acid: mechanisms of action and implications for human health. Journal of Physiology and Biochemistry 61:483-494.

14. Ha, Y. L., N. K. Grimm, and M. W. Pariza. 1987. Anticarcinogens from fried ground beef: heat-altered derivatives of linoleic acid. Carcinogenesis 8(12):1881-1887.

15. Clancy, K. 2006. Greener pastures: how grass-fed beef and milk contribute to healthy eating. Cambridge, MA, USA: Union of Concerned Scientists. 81 p.

16. Savory, A., And S. Parsons. 1980. The Savory grazing method. Rangelands 2:234-237.

17. Lasater, L. M. 2000. The Lasater philosophy of cattle raising. San Angelo, TX, USA: Santa Cruz Press. 116 p.

18. Smith, A. D. 1965. Determining common use grazing capacities by application of the key species concept. Journal of Range Management 18:196-201.

19. Bowns, J. E. 1989. Common use: better for cattle, sheep and rangelands. Utah Science 50:117-123.

20. Merritt, S., C. Prosser, K. Sedivec, and D. Bangsund. 2001. Multi-species grazing and leafy spurge. Sidney, MT, USA: USDA Agricultural Research Service TEAM Leafy Spurge. 28 p.

21. Hoffman, R. R. 1988. Anatomy of the gastrointestinal tract. In: D. C. Church [ED.]. The ruminant animal. Englewood Cliffs, NJ, USA: Prentice Hall. p. 14-43.

22. Funumoto, G. K., and J. R. Replogle. 1999. Pastured poultry production: an evaluation of its sustainability in Hawaii. University of Hawaii Cooperative Extension Service bulletin LM-1. 7 p.

23. Fanatico, A. 2006. Alternative poultry production systems and outdoor access. National Sustainable Agriculture Information Service (ATTRA) Publication No. IP300. National Center for Appropriate Technology. 24 p. 
24. Teague, R., F. Provenza, B. Norton, T. Steffens, M. Barnes, M. Kothmann, and R. Roath. 2008. Benefits of multi-paddock grazing management on rangelands: limitations of experimental grazing research and knowledge gaps. In: H. G. Schröder [ED.]. Grasslands: ecology, management and restoration. Hauppauge, NY, USA: Nova Science Publishers, Inc. p. $41-80$.

25. Adams, D. C., R. T. Clark, T. J. Klopfenstein, and J. D. Volesky. 1996. Matching the cow with forage resources. Rangelands 18(2):57-62.

26. Bingham, S. 1996. The last ranch: a Colorado community and the coming desert. New York, NY, USA: Pantheon Books. 363 p.

27. Howell, J. 2003. The Whitten Ranch-creating more with less. In Practice 90:8-12. Reprinted in J. Howell. 2009. For the love of land: global case studies of grazing in nature's image. Charleston, SC, USA: BookSurge. 209-223.

28. Whitten, G. 2005. In the mouth of the tiger-practicing Holistic Management on the edge. In Practice 102:9-12.

29. McClaran, M. P., and T. R. VanDevender. 1995. The desert grassland. Tucson, AZ, USA: University of Arizona Press. 346 p.

30. Nabhan, G., D. Blair, and D. Moroney. 2010. Ranching to produce tacos sin carbon: the low-carbon foodprint of grass-fed beef and sheep production in the semi-arid West. Quivira Coalition Journal 35:28-34.

31. Brand, D. R. 1961. The early history of the range cattle industry in northern Mexico. Agricultural History 35(3):32-39.

32. Roacho Estrada, J. O., E. L. Fredrickson, G. A. Bezanilla Enríquez, A. Gonzáles, H. R. Peinetti, and F. A. Rodríguez Almeida. 2009. Habitat use by Mexican criollo and British beef breeds in arid- and semi-arid environments of New Mexico and Chihuahua [abstract]. 94th Annual Meeting of the Ecological Society of America; 2-7 August 2009; Albuquerque, NM, USA. Available at: http://esameetings.allenpress. com/2009/Paper19351.html. Accessed 10 January 2011.

33. Roacho Estrada, J. O., E. L. Fredrickson, G. A. Bezanilla Enríquez, H. R. Peinetti, A. Gonzáles, And J. Ríos. No date. A comparison of grazing behavior between desert adapted Mexican criollo cattle and temperate British breeds using two diverse landscapes in New Mexico and Chihuahua [poster]. Available at: http://usda-ars.nmsu.edu/presentations/ octavio_Thesis.pdf. Accessed 10 January 2011.

34. Voisin, A. 1959. Grass productivity. Washington, DC, USA: Island Press. 353 p.

35. Savory, A., with J. Butterfield. 1998. Holistic management: a new framework for decision making. Washington, DC, USA: Island Press. 616 p.

36. Norton, B. E. 1998. The application of grazing management to increase sustainable livestock production. Animal Production in Australia 22:15-26.

37. Barnes, M. K., B. E. Norton, M. Maeno, and J. C. Malechek. 2008. Paddock size and stocking density affect spatial heterogeneity of grazing. Rangeland Ecology \& Management 61: 380-388

38. Howell, J. 2009. For the love of land: global case studies of grazing in nature's image. Charleston, SC, USA: BookSurge. $496 \mathrm{p}$.
39. USDa Natural Resources Conservation ServiceColorado. Practice specification guide: prescribed grazing (code 528). Denver, CO, USA. 5 p.

40. Reed, F., R. Roath, and D. Bradford. 1999. The Grazing Response Index: a simple and effective method to evaluate grazing impacts. Rangelands 21(4):3-6.

41. Howell, J. 2006. On Twin Creek Ranch-acting on "change requests" in the sagebrush steppe. In Practice 109:8-9. Reprinted in J. Howell. 2009. For the love of land: global case studies of grazing in nature's image. Charleston, SC, USA: BookSurge. p. 224-229.

42. Brown, D. E. 1994. Plains and Great Basin grasslands. In: D. E. Brown [ED.]. Biotic communities: southwestern United States and northwestern Mexico. Salt Lake City, UT, USA: University of Utah Press. p. 115-121.

43. Steffens, T. J., M. K. Barnes, and L. R. Rittenhouse. 2010. Graze period stocking rate, not stock density, determines livestock nutrient intake. Proceedings of the 4th National Conference on Grazing Lands; 14-16 December 2009; Sparks, NV, USA. Grazing Lands Conservation Initiative. p. 643-648.

Author is Director, Colorado Section SRM, and owner, ranch manager, and CPRM, Shining Horizons Land Management (www.shininghorizons.com), Cimarron, CO 81220-0122, USA, mattk.barnes@gmail.com. Meg Cattell, DVM, and Arden Nelson, DVM, are owners, Windsor Dairy LLC (www. windsordairy.com), Windsor, CO 80550, USA. Dale Lasater is owner, Lasater Grasslands Beef (www.lgbeef.com), Matheson, CO 80830, USA. Richard Parry is owner, Fox Fire Farms (www.foxfirefarms.com), Ignacio, CO 81137, USA. Kit Pharo is owner, Pharo Cattle Company (www.pharocattle.com), Cheyenne Wells, CO 80810, USA. George Whitten, Jr. and Julie Sullivan are owners, San Juan Ranch and Blue Range Ranch (www.bluerangeranch.com), Saguache, CO 81149, USA. Dennis Moroney is owner, Sky Island Brand/47 Ranch, McNeal, AZ 85617, USA; member, Sabores Sin Fronteras (Flavors Without Borders) Foodways Alliance (www.saboresfronteras. com); agriculture instructor, Cochise College; former President, Arizona Section SRM; and Vice-Chair, Baja Arizona Sustainable Agriculture. Ed Fredrickson and Alfredo Gonzáles are Research Rangeland and Animal Scientists, USDA Agricultural Research Service, Jornada Experimental Range, Las Cruces, NM 88003, USA. Gerardo Bezanilla and José Rios are rangeland and animal scientists, Universidad Autónoma de Chihuahua, Chibuahua, Chibuahua, México. Fredrickson also is Director, Southwest Grassfed Livestock Alliance. Harvey Sprock is an Area Rangeland Management Specialist, USDA-NRCS, Greeley, CO 80634, USA. Laurie Bower is Executive Director, Southwest Grassfed Livestock Alliance (www.grassfedlivestock. org), Santa Fe, NM 87505, USA. Carrie Balkcom is Executive Director, American Grassfed Association (www.americangrassfed. org), Denver, CO 80246, USA. 